\title{
Uniting a Divided Community? Re-appraising Jewish Responses to British Fascist Antisemitism, 1932-39
}

\author{
NIGEL COPSEY AND DANIEL TILLES
}

Traditionally, work on Anglo-Jewish responses to British fascism has concentrated on its 'workingclass', activist manifestations, particularly in east London over the period 1935-37, when Jews were prominently involved in confronting the British Union of Fascists. Such a focus has neglected other forms of Jewish activity, and this study examines two such aspects - early responses in the period up to 1935, and the defence work of the Board of Deputies of British Jews - drawing attention to the varying forms that Jewish opposition to domestic fascism took, as well as the different motivations that lay behind them. Furthermore, it challenges the perception that the communal leadership was unsympathetic to Jews who directly faced fascist antisemitism and ineffective in protecting them from it. Finally, it contests the belief that the debate over communal defence caused divisions within Anglo-Jewry, demonstrating instead that, while it certainly highlighted existing fissures, reflected in the varied initial responses to British fascism, the fascist threat eventually helped bring about greater unity and played a significant role in wider shifts in communal identity and power.

\footnotetext{
Dr Nigel Copsey is Reader in Modern History at Teesside University, UK. He specialises in historic and contemporary forms of fascism and antifascism. His major publications are Anti-Fascism in Britain (Palgrave, 2000) and Contemporary British Fascism: The British National Party and the Quest for Legitimacy (Palgrave, 2nd rev. edn, 2008). He is also co-editor (with D. Renton) of British Fascism, the Labour Movement and the State (Palgrave, 2005), (with A. Olechnowicz) Varieties of Anti-Fascism: Britain in the Inter-War Period (Palgrave, 2010), and (with G. Macklin) British National Party: Contemporary Perspectives (Routledge, 2010). Daniel Tilles is currently in the final year of a PhD at Royal Holloway, University of London, on the subject of interwar British fascist antisemitism and Anglo-Jewish responses to it. His research interests include European fascist history, modern Polish and Polish-Jewish history, and Western responses to the Holocaust. His chapter, "Some Lesser Known Aspects": The Anti-Fascist Campaign of the Board of Deputies of British Jews, 1936-40', will appear in the forthcoming volume The Jews in Britain, edited by Geoffrey Alderman, while previous publications include 'Inadmissible Evidence? Newly Discovered Archival Photographs of Nazi Atrocities Received by the British in March 1942', Totalitarian Movements and Political Religions, Vol.8, No.3-4 (September 2007).
}

Holocaust Studies: A Journal of Culture and History, Vol.15, No.1-2, Summer/Autumn, 2009, pp.163-187 PUBLISHED BY VALLENTINE MITCHELL, LONDON 


\section{Introduction}

While the British Union of Fascists (BUF), like the National Fascist Party in Italy, was founded with antisemitism absent from its programme, choosing to later integrate it into official policy, the obvious difference between the two was that, while in Italy antisemitism was adopted by an established, totalitarian regime, the BUF did so as a minor and faltering movement, able to claim just a few thousand supporters and no direct political influence. Consequently, opposition to fascism was easily able to find its voice in Britain, and disgust at the BUF's increasingly hostile attitude to Jews became a plank of Britain's antifascist movement. Indeed, Britain's fascists were far outnumbered by their opponents, as evinced by the 100,000 or more, a large proportion of them Jews, who turned out to block fewer than 2,000 Blackshirts attempting to march through east London in October 1936.

In terms of Jewish involvement in the 'East End' antifascist movement of the mid-to-late 1930s, much has been written. However, less attention has been paid to the period between the founding of the BUF in October 1932 and the peak of its antisemitic agitation in the months before and after the Battle of Cable Street four years later. The reasons behind this lack of focus on Jewish responses to the BUF before 1935 are clear. First, it is generally accepted that the movement did not adopt an official anti-Jewish policy until October 1934. Although there had been signs of a latent antisemitism before this time, Sir Oswald Mosley, the BUF's leader, had gone out of his way to reassure the Jewish community that his movement would not oppose any group on racial or religious grounds. There had also been little BUF activity in the Jewish districts of the East End before 1935. The assumption, therefore, is that because jews were not being victimised by Mosley's Blackshirts, no specific Jewish response had yet emerged. Secondly, it is the militant Jewish antifascism of the period from 1936 onwards that has become emblematic of Jewish opposition to domestic fascism, and the Battle of Cable Street in particular has captured the historical and popular imagination.

The prominence of East End Jewry in this narrative has also obscured, or at least skewed analysis of, responses from other sections of the Jewish community. In particular, the role of Britain's Jewish leadership has been underplayed or misrepresented, It has been portrayed as both unsympathetic to the plight of the working-class Jews who directly experienced fascist antisemitism, and ineffective in its action to counter this threat. Any measures that were taken have generally been dismissed as apologetic attempts to 'improve' Jewish behaviour and maintain control over the community, rather than to oppose Britain's fascists directly.

In this study, we revisit Jewish responses to fascist antisemitism in 1930s Britain. 
In the first place, we highlight that such responses to the BUF did not begin in 1935 or 1936, but in fact pre-date the arrival of the BUF in the East End. This activity, as we shall see, was variegated, and reflected sharp divisions within the community. Secondly, we offer a corrective to those historians who dismiss elite responses to fascist antisemitism as naïve and ineffectual. Thirdly, we argue that far from dividing the Jewish community, the fascist threat eventually brought it closer together.

\section{Early Organised Responses to the British Union of Fascists, 1932-35}

Despite strong denials that it was antisemitic, from its beginnings the BUF attracted opposition from sections of the Anglo-Jewish community, although often in spontaneous and unorganised form. During the spring of 1933 a significant hotspot developed in London's West End, where the BUF was active in its early days. The police noted that the Blackshirts were attracting 'unfriendly interest' from Jews, who often congregated around Coventry Street on Sundays. Understandably anxious about the increasing persecution of their co-religionists in Germany, many Jews were concerned that the BUF was using its publications to disseminate Nazi propaganda in Britain. ${ }^{1}$ This simmering tension boiled over in April and May, when conflict broke out between the two sides. On 30 April, a crowd of Jews, allegedly 1,000 strong, chanting 'Down with the Nazis; down with the Hitlerites', chased and surrounded a group of Blackshirts, seven of whom were arrested for refusing to leave the area. Skirmishes continued, however, and six Jews were arrested for various disorder offences, including two who had 'seriously pummelled' a Blackshirt. A week later, further clashes arose in the same area. Again, a large crowd of Jews had pursued a handful of fascists, this time attacking them once they caught up. Five Jews, four of them young men from the East End, were arrested for their involvement. Nearby, two more Blackshirts had been caught up in a violent fracas with another group of Jews, and both were eventually arrested 'for their own safety', in the words of the police. ${ }^{2}$ Such events were mirrored on a smaller scale elsewhere in London, with Jewish anger at events in Germany channelled into opposition to the BUF, which, despite Mosley's repudiation of antisemitism, was seen as a British incarnation of Nazism. ${ }^{3}$

Although at this early stage there was little by way of specifically Jewish organised opposition to the BUF, we do know that, whilst many political organisations, including the Labour Party, wished to avoid direct confrontation with the fascists, the Communist Party (CPGB) made early attempts, with some degree of success, to harness Jewish opposition to fascism. The CPGB, which had already identified Mosley as an incipient fascist in 1931, couched opposition to fascism in 
terms of class, rather than race. As a contemporary Young Communist League pamphlet put it, 'Hitler grinds the working-class Jew together with the working-class Aryan, not because of nationality, race or religion, but because of class'. ${ }^{4}$ The CPGB's position, in 1933, was that Jew and gentile alike should unite in a proletarian 'united' front against fascism.

In the East End, Communist efforts were channelled through a front organisation, International Labour Defence (ILD). In May 1933, ILD organised a demonstration at Liverpool Street Station against the visit of Hitler's emissary, Alfred Rosenberg, and linked this visit to the arrest of Jewish youths in the West End disturbances. ${ }^{5}$ Around the same time, there was an attempt to form a Jewish Lads Brigade Anti-Fascist Group, which urged class-based resistance to fascism. However, an injunction was taken out against this group by the Brigade's officers, and it was forced to disband. ${ }^{6}$ The following year, prior to Mosley's meeting at Olympia in June 1934, Special Branch reports indicate that the CPGB was especially active amongst Jews in the East End.' The same was true in the lead-up to a mass demonstration against Mosley in Hyde Park in September 1934, when it issued a leaflet in Yiddish calling on Jews to demonstrate against fascism and warning them to heed the lessons from Germany. ${ }^{8}$ Metropolitan Police reports estimate that the east London contingent on this march numbered over 1,600, and collections taken during its procession through the East End 'were well supported by the Jewish community'?

Trade unions also made efforts to enlist Jewish support. In March 1934 a leading figure in the National Amalgamated Union of Shop Assistants noted its 'great success in organising the Jews in the East End of London. ... The fascist menace ... is the main reason why they are flocking into our Union'. Later in the year, the National Union of Tailors and Garment Workers called on 'all Jewish workers to ... fight along with their English comrades against capitalism and reaction'. ${ }^{10}$

By the autumn of 1934 , the BUF had become openly antisemitic and, shortly after the Hyde Park demonstration, explicitly Jewish opposition to it, in the form of the Jewish Labour Council (JLC), emerged in the East End. This organisation, part of the Workers' Circle, a left-wing Jewish friendly society, published 30,000 copies of a leaflet entitled 'Sir Oswald Mosley and the Jews', which it distributed to thousands of British workers with the assistance of the Trades Union Congress. The leaflet offered an assessment of the BUF's antisemitism, noting its two-pronged attack on 'Jewish finance' on the one hand, and the 'sweepings of the ghetto' on the other, and arguing that it was imitating Nazi tactics. The JLC specifically refuted some of the fascists' 'foul lies', fearing that 'the ordinary British worker ... may wonder whether there is not some truth in them'. Their analysis was clearly influenced by their political stance, branding attacks on Jews a 'safety valve' for the 
ruling class to 'divert the wrath and discontent of the workers' away from themselves and the current socio-economic system, and labelling the BUF as 'the hirelings of reaction'. It finished by calling on 'the workers of the world [to] stand together, Jews and non-Jews alike'. ${ }^{11}$

Jews were also prominently involved in non-sectarian, non-party antifascist organisations. The most significant of these, originally founded in 1932, was the New World Fellowship (NWF). This opposed Mosley's BUF on the basis that fascism constituted a threat to democracy. The NWF styled itself as a broad-based national campaign group, open to both Jew and gentile. However, Jews, such as Maurice Isaacs, the general secretary, and Nathan Birch, director of propaganda, occupied its leading positions. During a six-month period in 1934, when the New World Fellowship was at its most active, it claimed to have held nearly 60 meetings in London and other large cities, addressed approximately 15,000 people on a weekly basis, and distributed over 1 million leaflets and booklets. ${ }^{12}$ What is interesting about the NWF is how its analysis ran counter to that of many within the AngloJewish establishment. Although it agreed with the Jewish Chronicle that 'antiSemitism had been brought to these shores to befoul the country', the NWF felt unable to rely on the 'fair-play' of the British to resist it. ${ }^{13}$ For fascism to be successful in Britain, it had to be 'definitely anti-Semitic', the NWF insisted..$^{14}$ Although it did not last much beyond 1934, this organisation represented a democratic, nonsectarian form of antifascism that continued in successor organisations such as the British Union of Democrats. This group, formed in the East End in February 1935, carried out an intensive campaign in East London against Mosley's Blackshirts in the summer of $1936 .{ }^{15}$

This brings us back to specifically Jewish responses to antisemitism. In February 1935 , an organisation was inaugurated for the purpose of counteracting antisemitism through propaganda. The launch of this body - the United Jewry Fellowship (UJF) - was triggered by concerns that the BUF would soon contest the 1935 general election, and that it might disseminate antisemitism across a vast number of constituencies. The UJF was critical of the inactivity of the Board of the Deputies, which for a period of 15 months, it claimed, had done nothing to counter antisemitism. It was also alarmed that Jewish youth was increasingly being attracted to extreme political movements because these 'appealed to the generosity of youth and had at least offered them one way of fighting anti-Semitism. ${ }^{16}$ The UJF wanted to give Jewish youth direction and deliver it from Communism, but it only ever really existed on paper - most likely because, as it turned out, the BUF decided against contesting the 1935 general election. Nonetheless, it quite clearly anticipates the criticisms directed at the Board of Deputies in 1936, and also prefigures the 
creation of the Board's own defence committee, which, like the UJF, concerned itself, at least initially, with anti-defamation and not antifascism.

\section{The Jewish Establishment and Early Responses to the British Union of} Fascists, 1932-35

Although it constantly monitored the situation, before 1936 the Board of Deputies of British Jews, the community's representative body, felt that domestic fascism did not present a serious enough threat to merit drawn-out discussion. Like the rest of the community, it was concerned by the worsening situation for Jews in Germany, but refused to draw any explicit links between the Nazis and the BUF. And although the increase in British fascist antisemitism in 1934 prompted the Board into action behind the scenes, including a series of private meetings with one of Mosley's lieutenants, ${ }^{17}$ its leadership, as we shall see, preferred not to engage publicly with the BUF, fearing that this would unnecessarily grant it publicity. For that reason, it is instructive to look elsewhere - to the pages of the Jewish Chronicle (JC) - for insights into the mentality of the Jewish elite. Even if editorially independent of the Board of Deputies, the JC has been described as Anglo-Jewry's 'semi-official' voice. Its editor, Jack Rich, was a former secretary of the Board and retained close links to it. ${ }^{18}$ Although prepared to criticise the Board, as a rule the JC's editorial line reflected the stance of the communal leadership, who, David Cesarani notes, 'could rely on [it] to broadcast their views'. ${ }^{19}$ As such, it reveals much about the early attitudes of the Jewish establishment.

It would be wrong to think that the Jewish elite was unconcerned by the formation of the BUF in October 1932. A few months earlier, the JC had taken interest in the immediate precursor to the BUF, Mosley's New Party. ${ }^{20}$ This had been occasioned by the arrest of a New Party member, an unemployed youth of 19, who had posted antisemitic labels on the window of a shop in London's Oxford Street. The JC advised Mosley that he 'would do well to sever the association' with the New Party of any members who were 'doing their best to give it an anti-Jewish tone'. ${ }^{21}$ It therefore came as little surprise that, having already voiced such concerns, it looked to Mosley for an authoritative statement on the subject as soon as the BUF was formed. Mosley duly obliged, declaring that antisemitism was no issue of fascism and formed no part of BUF policy.

The JC was deferential in its response to Mosley. Here was as an upper-class gentleman, someone who could be relied upon, trusted and respected. "We may feel sure that he himself is not one of those misguided people who see in the Jews the causes of all the present discontents in the world', it reassured readers in early 
October 1932. And so it was understandably 'perplexed' by Mosley's insistence that the BUF would not shy away from attacking Jews if they were involved in 'subversive', that is to say Communist, activities, or engaged themselves in international finance. ${ }^{22}$

Within weeks, the issue of antisemitism surfaced once more. At a meeting at London's Memorial Hall in late October, Mosley had responded to one or two Jewish hecklers with the retort that they should 'go back to Jerusalem'. 'If he is not antiSemitic', the JC responded, then Mosley 'has no right to single out for reprobation the Jewishness - such as it is - of some of his adversaries' ${ }^{23}$ Shortly thereafter, however; the newspaper felt able to apply some closure. In January 1933, Mosley categorically denied to the Jewish industrialist Lord Melchett that antisemitism formed any part of BUF policy, and this line was confirmed soon after in his newspaper, the Blackshirt, which labelled antisemitism an 'irrelevance' and noted that 'Jew-baiting in every shape and form [had been] forbidden'. The JC expressed relief that Mosiey had now 'definitely arrived at the safe haven of tolerance and common sense'. ${ }^{24}$

A good deal of the Jewish Chronicle's initial concern, it hardly needs saying, was occasioned by the developments in Germany. Naturally, the JC reported widely on these events. But the fact that the rise of political antisemitism appeared to be an indigenous German problem reinforced its view that Britain was different - that antisemitism was essentially 'alien' to British society, a continental contagion. Britain, it held, was characterised by freedom, tolerance, justice and fair play. Antisemitism, in contrast, was viewed as a moral and mental disease' that afflicted the European mainland. What is more, the JC was as keen as Mosley to discriminate between the ideology of Hitler and that of Mussolini. Italian Fascism, which Mosley claimed as his inspiration, had no truck with antisemitism, the JC insisted. Antisemitism was not intrinsic to fascism, and therefore fascism was not a concern for Jews as a whole. In order to minimise any possibility that the continental virus of antisemitism might spread to Britain, the JC wanted its co-religionists to avoid violent confrontation with the BUF. Jewish hostility might tempt Mosley towards Hitlerism and, while the JC believed that British society was liberal and tolerant, could also stir up wider antipathy to Jews by drawing attention to their distinctiveness. The logic behind such thinking was that where antisemitism occurred in British society, it was largely down to the actions of Jews themselves.

This reasoning accounts for the JC's response to the abovementioned disturbances between Jews and British fascists in London's West End in the spring of 1933. Interviewed by the JC, Mosley insisted that neither he nor his organisation were antisemitic. 'Our attitude in this respect', he declared, 'is very similar to that of Italian Fascism, where attacks upon Jews are unknown'. He reiterated that within 
a month of its founding, an order had been posted in all BUF premises forbidding Jew-baiting in any form. ${ }^{25}$ This theme continued through the summer, with the JC noting in July Mosley's proclamation that, despite 'some of our members hav[ing] been maltreated by Jews $[$,$] ... we are not anti-Semitic' { }^{26}$ For the JC, such repudiation was unequivocal, and it called those Jews who took part in street disturbances to order. 'Instead of helping the Jewish cause', it said, 'they are betraying it. ... We shall not improve things by figuring in street riots and degrading ourselves by copying Nazi violence which we loathe and detest. ${ }^{27} \mathrm{~A}$ few months later the newspaper went even further, condemning those 'few feather-brained individuals' who carry out 'wicked and stupid' attacks on the Blackshirts, who have 'repeatedly declared that they are not anti-Semitic'. 'After all', it continued, 'Signor Mussolini has shown that Fascism does not necessarily imply anti-Semitism. If the Hitlerists' besotted mentality has confused the two, that is no reason why Jews should come to blows with an organisation which avowedly does not. ${ }^{28}$ This stance certainly mirrored that of many within the Jewish establishment. The Association of Jewish Youth, for example, complained to the Board of Deputies of the 'wholly undesirable ... activist tendencies' of many East End Jews, persuading its president, Neville Laski, to organise meetings in the area to remind Jews of the 'importance of restraint'. ${ }^{29}$

But Mosley's association with antisemitism would not go away. In September 1933, the JC learned that a BUF delegation had visited Nuremberg on the invitation of the Nazi Party. ${ }^{30}$ Then, two months later, following an article in the Blackshirt entitled 'Shall Jews Drag Britain to War?', it challenged Mosley to account for his apparent volte face. ${ }^{31}$ Returning to the subject of antisemitism in January 1934, the JC criticised Lord Rothermere and his Daily Mail, which had declared support for the BUF, for 'whitewashing the Blackshirts' ${ }^{32}$ It also sent a brave correspondent to the Chelsea headquarters of the BUF to enquire as to how the BUF's protestations that it was not antisemitic could be reconciled with an attack on Jews made by a leading BUF official, William Joyce, at a recent meeting at Chiswick Town Hall. ${ }^{33}$ When BUF representatives refused to distance themselves from Joyce's statements, the editor of the JC wrote to Mosley pressing for clarification, especially as the newspaper had learned that Jews were now banned from BUF membership in London. Despite repeated telephone enquiries, no reply from Mosley was ever received. Meanwhile, further attention was drawn to antisemitic comments by Mosley, including a remark in his speech at Olympia in June 1934 that 'free speech has been abolished by hordes subsidised from Moscow gold and carrying weapons never seen in England until the Ghettoes were emptied on our shores'. The weeks after Olympia saw a dramatic rise in such rhetoric, with Jews repeatedly accused of violently attacking the movement. ${ }^{35}$ 
The following month Rothermere broke with Mosley. The JC applauded the decision, drawing attention to the press magnate's comment that he 'could never support any movement with an anti-Semitic bias ${ }^{36}$ For the JC, this repudiation of antisemitism represented the 'best and noblest traditions' in British life. It then took a set of norms that it assigned to British culture and traditions and conflated them with the Jewish faith and customs. What underscored Jewish teachings, it said, was a sense of justice and fair play. Accordingly, Jews that interfered with free speech were being not only disloyal to Jewish teachings but also to the values of their host society and, thus, unpatriotic. Such a response quite clearly reveals the assimilationist-type mentality that characterised the Anglo-Jewish elite - in other words, a desire to express commitment to British citizenship, values and culture through reference to corresponding features in Judaism and the Jewish tradition. Hence, 'Our answer to Sir Oswald', the JC declared in July 1934, was for Sir Oswald to 'Be British!' ${ }^{37}$

At the Albert Hall in October 1934, Mosley further elucidated the BUF's now undisguised antisemitism, launching a sustained attack on both 'the little men who come out of Whitechapel' and the 'big men' in the City of London. Such was the antisemitic tenor of this speech that the Italian fascist daily, Regime Fascista, roundly condemned Mosley for imitating National Socialism. 'True Fascism, which was created by Mussolini', Regime Fascista warned, 'knows nothing of the domination of one race over another, and religious conflicts and antagonisms are alien to it. ${ }^{38}$ Nonetheless, there was still no need for active Jewish opposition, the JC maintained. The reason: Mosley was now 'merely aping Hitlerist tactics' and this was the 'gambler's last throw'. 'He will lose, He is losing.' 'In time', the JC concluded, 'Mosley will learn that Britain is not Germany and has no use for the garbage rummaged from the dustbins of Continental anti-Semitism. ${ }^{39}$ In other words, in Britain's liberal and tolerant society, Mosley was destined to fail - its traditions of justice and fair play constituted a formidable barrier to the growth of antisemitism. The problem with such an analysis, as both the JC and the Jewish communal leadership would discover from 1935 onwards, was 'the contradiction between the community's earlier predisposition to dismiss the possibilities of antisemitism in Britain and its increasingly experienced reality', as David Rosenberg eloquently puts it. ${ }^{40}$ Nowhere would this contradiction become more apparent than in London's East End.

Throughout the period 1932 to 1935, the Jewish Chronicle sought elucidation of Mosley's position and never bitterly attacked him. In the first place, this clearly reflected a desire to demonstrate fair play, a quality that it assigned to both British and Jewish traditions. Second, the JC was concerned not to lend credence to 


\section{HOLOCAUST STUDIES: A JOURNAL OF CULTURE AND HISTORY}

Mosley's claims that Jews were openly hostile to fascism and to the BUF. But perhaps most importantly, it was reluctant to accept, on account of his intelligence and aristocratic upbringing, that Mosley was truly antisemitic. Antisemitism, it thought, was restricted to the grubby lunatic fringe - people like Arnold Leese, leader of the Imperial Fascist League, who arraigned Mosley for his 'pro-Jew' policy. In fact, Leese's attack on the BUF, which was reported in the JC, only gave more credibility to Mosley's claim that his fascism, like Mussolini's, was devoid of antisemitism. Initially, despite evidence of 'cloven-hoofed' antisemitism, the JC had taken Mosley at his word. Then, when the BUF adopted an openly anti-Jewish stance, the JC dismissed this as an irrational 'flight towards Hitlerism' that would never get off the ground. Only when it did, when antisemitism struck a respondent chord in London's East End in particular, did the JC change tack. Only then, in 1936, did it call on the leaders of the Jewish community to take a more active role in responding to domestic antisemitism.

\section{The Board of Deputies' Initial Response to the East End Campaign}

Not only did the BUF focus much of its activity, and especially its antisemitism, on the East End from 1935 onwards, but this was also, not coincidentally, where the highest concentration of Jews in Britain was to be found. Consequently, the area became the epicentre of a rapidly developing conflict. It has been the actions of these east London Jews (often relatively poor, first- or second-generation immigrants) that have come to dominate historical accounts of Jewish responses to fascist antisemitism in Britain. This is perhaps not surprising, given that this 'working-class' Jewish response represented the most visible, and superficially the most effective, challenge to British fascism. A number of Jews became involved in militant antifascism, disrupting BUF events and clashing with Blackshirts on the streets, while organised bodies, such as the Jewish People's Council against Fascism and Anti-Semitism (JPC), attempted more formally to counter the fascist threat in the East End.

This focus on East End Jewish antifascism has caused the response of the AngloJewish elite, and particularly the Board of Deputies, to become somewhat obscured, or, where it is acknowledged, to be dismissed as unsympathetic and ineffective. Scholars have criticised the Board for centring its efforts to tackle antisemitism around 'improving' Jewish behaviour, rather than confronting the fascists and their propaganda directly, and for being more concerned with maintaining its monopoly over communal defence than actually protecting the community. This perspective, no doubt, has sprung in part from the influence of the numerous contemporary 
accounts in which East End Jews were vocally and publicly critical of the Board, which they viewed as aloof and out of touch. In contrast, much of the work of the Board and the attitude of its leadership was kept out of the public eye, and has had less of an influence on later research.

Elaine Smith brands elite responses to fascist antisemitism as 'weak', and criticises the Board for 'believ[ing] that Jews themselves were largely responsible for creating antisemitism by their actions and behaviour'. 'il Gisela Lebzelter accuses the Board of being 'extremely reluctant to fight antisemitism', describing its attitude to defending the community as 'apologetic' and 'naive', ${ }^{\text {,2 }}$ while Neil Barrett condemns. it for being more concerned with keeping the community under control than with fighting antisemitism. ${ }^{33}$ Cesarani accepts that the Board had a 'mixed record' when it came to antifascism, but labels its defence of Jewish rights as 'lacklustre' nonetheless. ${ }^{44}$ Finally, Geoffrey Alderman has criticised some of the Board's defence work for its 'timidity and condescension', going as far as to claim that its actions actually strengthened antisemitism. And he too is critical of the Board's desire to police the community, claiming it was more concerned with preventing Jews from exacerbating antisemitism than with countering the fascist threat. ${ }^{45}$

While these accounts offer one interpretation of 1930 s communal defence, their findings are coloured by a rather one-sided approach. Although the Board's archives are readily accessible, many historians have ignored or underused this resource, instead examining Jewish responses largely from an 'East End' perspective. Lebzelter and Barrett, for example, assess the Board's role with almost no reference to its own records, while Smith's research is specifically focused on the Jewish East End. Furthermore, while the picture they paint in many ways holds true for a certain period of time - the Board did indeed struggle at first to come to terms with the growing threat of fascist antisemitism - it fails to take account of the significant and relatively rapid developments that took place over the final years of the decade.

Although it had monitored anti-Jewish activity through the 1920s and early 1930s, it was only after the BUF began to concentrate its antisemitism in the East End that the Board contemplated a more active defence policy. This change of tack was in part forced upon it by intra-communal pressure, and not just from east London Jewry. The JC, which, as we have seen, had hitherto adopted a cautious attitude to defence, began in 1936 to demand a more robust approach, running a regular section entitled 'Jewish Defence' that reported on antisemitic incidents and published letters critical of the Board's passivity. Within the Board itself, too, there were calls from certain deputies for the establishment of a body to coordinate defence activity. ${ }^{46}$

Although he initially resisted such pressures, Laski, the Board's president, was eventually forced to compromise. At a meeting in July 1936 it was agreed to create 


\section{HOLOCAUST STUDIES: A JOURNAL OF CULTURE AND HISTORY}

the Co-ordinating Committee $(\mathrm{CoC})$, which was tasked with harmonising efforts to monitor and prevent attacks on the community. (In late 1938, the body was relabelled the Jewish Defence Committee (JDC) to reflect the more specific and active role it was taking in communal defence. $)^{47}$ However, tensions remained, with some deputies demanding the establishment of an autonomous defence organisation that would follow an 'open and aggressive policy of countering Fascist activity'. Following an unusually 'offensive ... and bitter' debate, the outnumbered rebels were eventually quelled, and agreed to pursue their scheme independently. ${ }^{48}$ As well as continuing to monitor antisemitic individuals and organisations, the Board's defence policy was now divided into four main strands. ${ }^{99}$ The first was a propaganda campaign with the twin aims of countering specific antisemitic claims and of informing the British public of the positive contribution the Jewish community made to society. These efforts involved producing publications, ${ }^{50}$ writing letters to newspapers ${ }^{51}$ and holding meetings ${ }^{32}$ While no one could criticise the Board for a lack of activity in this direction - it distributed over 2 million publications and held hundreds of meetings a year ${ }^{33}$ - many have condemned its propaganda as apologetic, as demeaning Anglo-Jewry in an attempt to prove to gentiles that Jews were worthy citizens. For its part, the Board was aware of these accusations and offered the response that, although 'one cannot hope to convert an anti-Semite', the majority of those who felt ill towards Jews did so 'not through prejudice but through ignorance' It was therefore its duty to ensure that all gentiles were furnished with the truth about the Jewish community. ${ }^{54}$ It was also felt that if the lurid accusations made by fascists against Jews were left unanswered, many might assume them to be true. 5.

A second strategy was to maintain regular contact with the authorities. This served two purposes: to keep the police and Home Office informed of anti-Jewish activity, and to put pressure on them to take action against those involved. The Board's view was that not only was the Jewish community limited in what it could achieve independently to restrict antisemites, but that attempting to take action as Jews would simply supply more ammunition to the fascists, who already claimed to be the victims of Jewish attacks. As such, Laski maintained regular contact with successive home secretaries and commissioners of the Metropolitan Police, as well as various mayors and MPs.

While these first two approaches reflected the Board's wish to shape gentile opinion, other efforts were aimed within the Jewish community itself. Above all, Jews were publicly implored not to involve themselves with militant antifascism. It was argued that the kind of disruptive activity practised by many East End Jews simply provided the fascists with much-needed publicity. Newspapers only reported 
on fascist events when disorder had occurred, nearly always as a result of antifascist heckling or physical disruption, and the Board's view was that preventing such activity would deny the fascists attention and any public sympathy. ${ }^{56}$ Moreover, as Mosley insisted that his movement had been forced to adopt antisemitism because of victimisation by Jews, the Board was keen to avoid providing any justification for this claim.

This attitude towards militant Jewish antifascism was strongly influenced by external advice the Board received. The Home Office informed Laski that it was usually Jewish hecklers who caused trouble at fascist meetings, and the police, while accepting that the BUF was deliberately provocative, warned that as long as Jews and others attend the [fascist] meetings and indulge in "baiting" the speakers, such occurrences [of violence] are almost inevitable'. Sir Philip Game, the commissioner of the Metropolitan Police, urged the Board to 'do anything to bring [Jewish antifascists] to a more sensible frame of mind', arguing that 'if deprived of publicity and more or less ignored, the BUF's wings would very soon be clipped' ${ }^{57}$ Similarly, at a meeting with the mayors of Stepney, Poplar and Hackney, Laski was informed that many Jews, especially those 'intermeddled with Communist activities', were heavily involved in the cycle of violence between the fascists and their opponents, and it was recommended that 'repressive measures of a strong and immediate character' be taken. ${ }^{58}$

The final, and most controversial, element of the Board's defence campaign was its efforts to 'improve' the behaviour of certain elements in the community. Much of the BUF's antisemitism exploited grievances against Jews that resulted from their alleged commercial and social shortcomings. It was claimed that Jewish landlords mistreated their tenants, shopkeepers killed off gentile competitors with underhand business practices, and that jews in general were alien and undesirable. While fascist accusations were usually untruthful or greatly exaggerated, the Board realised that there were examples of illegal or immoral behaviour within the community, and felt that preventing these would help stem the appeal of antisemitism. This attitude has elicited criticism from those who feel that the Board were not only accepting the validity of anti-Jewish claims but, by highlighting undesirable activity within the community, actually provided ammunition to antisemites. ${ }^{59}$

The Board's approach in this matter again reflected wider criticism of Jewish behaviour and calls for action to be taken. Ivan Greenberg, editor of the JC from December 1936, used the newspaper to argue that antisemitism in large part sprang from the supposedly low ethical stands of Jewish businessmen, even condemning 'vulgar displays' of wealth by Jews. ${ }^{60}$ At the abovementioned meeting with east London mayors, Laski heard that Jewish property agents 'resorted to every indecent trick and device, causing an enormous amount of trouble and a great deal of ill- 


\section{HOLOCAUST STUDIES: A JOURNAL OF CULTURE AND HISTORY}

feeling, this being cleverly turned by the Fascists into anti-Semitic feeing'. They alleged that a majority of prosecutions by the Public Health Department were against Jewish property owners. ${ }^{61}$ These complaints were reinforced when, three days later, Laski met Herbert Morrison, the Labour leader of the London County Council, and Harry Pollitt, general secretary of the CPGB, who both agreed that the practices of many Jewish landlords and employers were stirring discontent. ${ }^{62}$ Allegations against Jewish traders and employers were also substantiated by various trade groups, as well as a London magistrate who, after fining a Jewish milkman, lamented that this was 'yet another instance ... of a Jewish tradesman cheating the public'. ${ }^{63}$

Whatever the validity of such complaints, as Anglo-Jewry's representative body, the Board felt compelled to lead the communal response. Its Law, Parliamentary and General Purposes Committee had already been monitoring trade disputes involving Jews, intervening when necessary to find 'amicable arrangements', and its activity took on a greater sense of urgency as the BUF's antisemitic campaign was stepped up. The 1936 Shops Act, which allowed limited Sunday trading for practising Jews, had established a 'Jewish tribunal' to deal with those alleged to have contravened the new rules, and this was manned by prominent Jews nominated by the Board. ${ }^{64}$ In 1938, the Trades Advisory Committee was established as an offshoot of the $\mathrm{CoC}$, with the specific task of tackling the factors underlying trade-related illfeeling towards Jews. ${ }^{65}$ Laski himself pronounced that Jews should 'tidy up our own house', although he was at pains to stress that only a 'few individuals' were guilty of any malpractice and that they should be judged by the same standards as gentiles, many of whom were also involved in disreputable behaviour. ${ }^{66}$

Clearly this approach left the Board open to accusations of hypocrisy. On the one hand Jews were implored to allow the authorities to deal with antisemitism and not to take matters into their own hands, but when it came to criminal Jewish behaviour, this was an issue for the community itself to tackle, rather than leaving it to the relevant authorities. And while trying to prevent illegal conduct could be justified, the Board's attempts to persuade Jews to avoid lawful but unpopular business practices and ostentatious behaviour was, as Alderman argues, akin to asking them to accept second-class status. ${ }^{67}$

It has been claimed that the establishment of the $\mathrm{CoC}$, rather than signifying the Board's willingness to tackle the propagators of antisemitism, was merely aimed at reinforcing its existing defence policy of communal improvement and quiet propaganda ${ }^{68}$ Certainly it does appear that in 1936 there was a failure to fully comprehend the significance and nature of the BUF's growing antisemitism. As we have seen, the belief of many within the communal elite was that this was a mere 
imitation of Nazi methods, with little genuine appeal in Britain, adopted to prop up a failing movement. Sir Philip Magnus, who chaired the CoC's publications subcommittee, typified this view in a report, "British Fascism" and the Jews', penned in late 1936. He saw Mosley's anti-Jewish agitation as 'a desperate endeavour ... [to] save the ship of his variegated political career from complete and final shipwreck ... [by] attaching to himself such a measure of cheap popularity as may be won by an appeal to old anti-semitic prejudice'. He argued that this represented a move by the BUF towards the Nazi model, and was supported in this belief by Sidney Salomon, the secretary of the $\mathrm{CoC}$, who alleged that the Nazis were 'visibly behind much ... that officially bore the stamp of this new party'. Magnus' recommendation that 'the simple truth appears to be the best reply', in the form of propaganda exposing fascist lies and highlighting the worthiness of the Jewish community, clearly supported a continuation of existing defence policy. ${ }^{69}$

The Board was also keen to uphold its tradition of remaining aloof from politics and this, along with an insistence on respecting freedom of speech, meant that, initially at least, it refused to condemn fascism per se, insisting it would protest against antisemitism but not against a legitimate political party. A letter from a senior Board official noted that 'however much we may dislike the Fascist programme and, in particular, the anti-Semitism which is so prominent a feature[,] ... we have no right ... to interfere with freedom of speech'.$^{70}$ Magnus' report, too, recommended disentangling the main tenets of fascist ideology - 'with which, as Jews, we have no quarrel' - from the antisemitic elements. ${ }^{71}$

Furthermore, at this stage the Board's approach was clearly influenced by a disapproval of working-class Jewish activism and a desire to protect its own position and the image of the community. Laski privately condemned 'the gangsters of the Community, who for one reason or another are exploiting the situation in a manner which may well be dangerous to the Community'? ${ }^{2} \mathrm{He}$ also did little to disguise his anger at the attempts of Jewish antifascist bodies to, in his words, 'assume functions which only the Board was entitled to exercise'. He was particularly galled by the JPC, which had been formed in July 1936 in protest at the Board's lacklustre approach to defence and had attempted to make independent approaches to the authorities, something Laski viewed as the Board's unique prerogative. ${ }^{73}$ As such, the president did his best to make clear to the police, government and media that the JPC was 'not a body which commands respect in responsible Jewish quarters' ${ }^{74}$ The fact that the JPC, and Jewish antifascists in general, appeared to have strong links to the Communist Party further deterred Laski from dealing with them. ${ }^{75}$ Not only did the Board wish to remain apolitical, it certainly could not be seen to be consorting with left-wing revolutionaries who aggressively confronted their opponents. 


\section{The Evolution of Communal Defence, 1937-39}

The image of the Board presented thus far largely conforms with traditional historical accounts. However, what they have not fully recognised is how its stance developed, leading to a more sympathetic and active approach to defence. This change in attitude resulted in large part from numerous reports that arrived throughout 1936 and 1937, outlining the continued and growing menace of fascist antisemitism, the increasing anxiety of the Jews who faced this threat, and the failure of the authorities to properly control the situation. One, for example, noted that, despite the BUF's electoral failings in 1937 and the implementation of legal restrictions against it, there were 'no signs of [a] reduction in the abuse that is levelled at the Jews' in the East End; in fact, the BUF was redoubling its efforts there, particularly in areas with large Jewish populations. It warned that the situation 'would require very little to burst into flames. ${ }^{76}$ Laski himself acknowledged in late 1937 that 'anti-Jewish activity seems to be on the increase'?

The Board quickly accepted that political antisemitism was not an ephemeral and marginal phenomenon and that it was inextricably linked to Mosley's movement, which, it was now recognised, had to be opposed. International developments no doubt influenced the Board's position, too, although their effect should not be exaggerated. The introduction of racial laws in Italy in 1938 made it much harder to argue that antisemitism was not inherent to fascism, while German aggression in 1938-39 made an antifascist position more acceptable. Scholars have contended that it was only after these events that the Board accepted the need to oppose British fascism. ${ }^{78}$

However, it is clear that this change came much earlier, preceding developments abroad. By spring 1937 the CoC had released two antifascist publications AntiSemitism in the East End' and 'Do you know these facts about Mosley and his Fascists? ${ }^{\text {?9 }}$ Later that year, Laski hired investigators to examine the BUF's finances for any irregularities that could be used against it, indicating that he was now willing to oppose Mosley's movement, and not just its antisemitism. ${ }^{80}$ The Board also managed to infiltrate agents into leading fascist organisations, including the BUF, and the evidence they provided was used to keep the authorities informed of fascist activity and to help identify the fascists who were interned by the government in $1940{ }^{81}$ And despite its desire to remain politically neutral in public, the Board carefully monitored the BUF's election results in March 1937, privately celebrating its failure as 'gratifying' ${ }^{82}$ Despite this setback - or perhaps because of it - the BUF intensified its focus on predominantly Jewish areas of the East End, with Laski noting that this was 'causing me some anxiety'. In 1937 he explored legal avenues 
for banning marches in these districts, while petitioning the authorities the next year to introduce restrictions on fascist activity. ${ }^{83}$

These efforts signified that the Board had come to better understand the distressing situation that faced East End Jews and to take more seriously its duty to represent this section of the community. As early as July 1936, a deputation of the three most senior Board officials had met Sir John Simon, the home secretary, to discuss the situation in the East End. They emphasised that the BUF's campaign of verbal and physical attacks had led to a 'feeling of insecurity and alarm among the Jews'. Although they would always advise the community to act with restraint, 'human nature had its bounds' and a backlash was inevitable, especially given 'the apparent immunity and license enjoyed by the fascists' ${ }^{84}$ The next March, Laski informed the undersecretary of state of continuing problems, warning that 'any selfrespecting Jew in the crowd [at fascist meetings] would have the greatest difficulty in restraining himself, not only vocally, but even physically' ${ }^{85}$ There were public expressions of sympathy too, with Salomon telling the Evening Standard in November 1936:

There have been a few cases of assault in which Jews have been embroiled. We discourage it strongly, but what can you expect? Is a Jew who is a British subject going to stand calmly by while Blackshirts shout insults at him? It is not human nature. ${ }^{86}$

By mid-1937, the Board was prepared for the first time to use its privileged position to help the JPC forward a complaint to the authorities, relating to an incident in the East End at which a number of Jews had been arrested following a fascist meeting. Certainly the Board made no pretence to support the JPC's claims indeed, Laski commented that he was merely allowing them to 'blow off steam' - but it was significant that it was now prepared to work on behalf of this unofficial Jewish organisation. Later in the year the JPC again approached the Board, this time for mediation in industrial disputes involving Jews and to request assistance for an antifascist facing trial. ${ }^{87}$ The authorities also used the Board to convey messages to the JPC, with whom they wanted no official contact, and over the following years Laski became something of a conduit between the two sides. ${ }^{88}$ Leading figures within the Board were even prepared to side with East End Jews in their grievances with the authorities, with one complaining of the 'rather truculent attitude of the police', and Laski himself suggesting to the Home Office that police action against Jews responding to antisemitism at fascist meetings was 'a little hard on the interrupter' ${ }^{89}{ }^{89}$

In recognition of the specific threat faced by Jews in the East End, the Board decided that it should establish a permanent presence in the area, and in 1937 set 
up the London Area Council (LAC), which, by organising meetings, distributing literature and monitoring fascist activity, aimed to 'vigorously counter the Blackshirt menace. ${ }^{90}$ The Board was now well positioned to build a relationship with the JPC, which had always left the door open to collaboration. In its early days it had made clear that it did not wish to rival the Board, passing a resolution calling for the two to join in a united front against fascism; by mid-1937, one observer noted that the JPC was 'becoming more moderate in its views and is anxious to enlist [the Jewish establishment's] support'.91 Throughout 1938 discussions took place between the LAC and the JPC about unifying their defence work, and, as a sign of this growing convergence, the JPC's secretary was invited to speak at an LAC conference that summer. However, although both sides agreed that it was desirable to have just one Jewish defence organisation, the Board's insistence that the JPC should therefore be disbanded was unacceptable to the latter. Despite these misgivings, the two bodies did agree to work alongside one another for a six-month period in $1939 .{ }^{2}$

This improving relationship represented an important convergence between these two sides of Britain's Jewish community, in regard to their understanding of the fascist threat and of the need to work in tandem against it. As we have seen, the Board's leadership came to accept that antisemitism and fascism could not easily be disentangled from one another, and that it had perhaps been failing to properly represent certain sections of the community. For their part, many Jewish antifascists began to see that fascism was not a serious political threat and that militant activity simply served to grant it publicity. No doubt, too, there was a strong element of expediency in this increasing unity. Both sides remained wary of one another, and the relationship that developed was never particularly close; in many ways it was a forced alliance to confront a common enemy. The Board, which received warnings of the criticism it faced in the East End and of the JPC's popularity there, ${ }^{93}$ was keen to neutralise any threat to its monopoly on communal defence and realised that absorbing the JPC would be more effective than undermining or ignoring it. ${ }^{94}$ For Jewish antifascists, frustrated by their failure to establish contact with the authorities, an alliance with the Board provided access to decision-makers and an opportunity to influence official policy.

However these factors alone cannot explain the growing willingness to collaborate, and it is certain that both sides began to appreciate that there was actually much in common between their aims. On its founding, the JPC had outlined its three chief objectives as: uniting the Jewish community against its enemies; co-operating with other antifascist bodies; and warning British society that fascist antisemitism was a precursor to attacks on the liberties and rights of all people. ${ }^{95}$ On the first issue, clearly the Board shared the aim of presenting a unified 
communal response (albeit under its own auspices). And while it was not prepared to cooperate with militant antifascist groups, it did support the JPC's stance that Jews should work with democratic institutions to eradicate antisemitism. ${ }^{96}$ On the final point, the Board's attitude gradually converged with that of Jewish antifascists, and by the late 1930s it was publicly arguing, exactly as the JPC had been, that political antisemitism 'always ends in general violence and support of retrogressive movements' and that fascism is 'an ideology directed towards the destruction of all that is good in human values, true religion and human liberty'. ${ }^{97}$

This increasing overlap has been neglected by many scholars, who argue that fascist antisemitism helped highlight and then exacerbate divides within the community. ${ }^{98}$ The period up to late 1936 had indeed revealed sharp contrasts. But these were a manifestation of pre-existing divisions between established, anglicised Jews and more recently arrived, working-class immigrants, rather than evidence of new fissures. The convergence that ensued over the following three years demonstrates the evolution of attitudes on both sides and a realisation that confronting antisemitism was of greater importance than intra-communal disputes. Far from dividing the community, the fascist threat in fact brought it closer to together. And, as if to symbolise this greater unity, upon his retirement as president in 1939, Laski was replaced, in an uncontested election, by Selig Brodetsky, a Russian-born Jew brought up in the East End, but who had risen to become a Cambridge-educated academic and mixed readily in high circles."

What is also apparent is that the Jewish community's measures to counter fascist antisemitism in the period 1936-39 achieved a significant level of success. Laski's constant contact with the police and the Home Office kept the authorities informed of antisemitic activity and the perspective of the Jewish community. It was also instrumental in encouraging the introduction and continued implementation of antifascist legal measures that restricted British fascism, and, indeed, in helping bring about the BUF's eventual collapse by assisting with the internment of leading fascists in 1940. And the Board's much-criticised propaganda campaign did much to negate the anti-Jewish rhetoric that underpinned the BUF's programme after 1935. This did leave it open to charges of producing mere apologia, but given that prejudice against Jews was relatively widespread in Britain, it is not hard to understand why the Board felt compelled to respond to the lies propagated by the fascists. It would surely have been remiss to have allowed attacks on the community to remain unanswered.

While the Board may have reached a degree of accommodation with the JPC, it did not succeed in completely preventing Jewish militant antifascism. However, this failure actually proved to be unintentionally beneficial. Although Laski correctly 


\section{HOLOCAUST STUDIES: A JOURNAL OF CULTURE AND HISTORY}

judged that disruption of fascist events attracted media attention, the benefits this publicity brought are debatable. Clashes such as the Battle of Cable Street resulted in influxes of new fascist recruits, but these were not committed fascists, often attracted simply by the prospect of violence, and they usually left the movement quickly. ${ }^{100}$ And in the long run, antifascist activity helped associate the BUF with conflict and violence, deterring potential supporters and hampering its attempts to function as a conventional political party. Furthermore, by attacking fascist meetings and marches, antifascists disrupted the BUF's main outlet for its propaganda, further limiting its attempts to attract support. Laski may even have come to understand these benefits: when commenting on 'the policy of aggressivism', he noted that 'on occasion' such tactics 'have their utility'. ${ }^{101}$

What resulted, therefore, was an effective, although largely uncoordinated, twopronged attack on fascism by the Jewish community. At one end of the scale, lobbying and propaganda by the Jewish elites helped bring about legal measures against the BUF and undermined its antisemitic rhetoric; at street level, Jewish antifascism brought the BUF negative publicity and limited its ability to communicate its programme. This effect analogises to Nigel Copsey's analysis of broader British antifascism. Copsey observes that militant antifascists, led by the communists, disrupted fascist activity and tarnished the BUF's image, while at a higher level the Labour Party's refusal to abandon its commitment to political moderation and liberalism helped marginalise and delegitimise [the BUF]'. Although uncoordinated, together these efforts restricted the political space available to fascism, ${ }^{102}$ and the work of the Board and Jewish militant antifascists combined in similar fashion, contributing significantly to the demise of fascism in Britain.

\section{Conclusion}

While the Jewish establishment may have been sensible to call for restraint in responding to the BUF in its early years, it is clear that its initial analysis of Mosley's adoption of antisemitism was flawed. It mistakenly saw political antisemitism as an alien creed, which would be short lived and ineffective. This belief - expressed through the pages of the Jewish Chronicle and apparent in the Board of Deputies' policies up to 1937 - was defined by a set of preconceptions about the supposedly innate tolerance and fair play of British society. These fixed notions led it to denude antisemitism of any serious potential for growth, especially if Jews respected British (and corresponding Jewish) traditions of fair play, justice and free speech. Jews were therefore called on to avoid confronting the BUF, lest they push Mosley towards Hitlerism and afford antisemitic claims any credibility. Secondly, the 
relationship between antisemitism and fascism was downplayed. The fascism of Mussolini, the JC claimed, was a fascism that 'never singles out Jews but exalts Jewish individuals', whereas Hitlerism was an irrational aberration. ${ }^{103}$ Such a position allowed the Anglo-Jewish elite to distance itself from antifascism - a politics that it identified with the militant left - and suited the Board's apolitical stance. Finally, once it became clear that Mosley's association with antisemitism was far from ephemeral, the Anglo-Jewish establishment initially remained confident that an anti-Jewish policy would never find favour in British society - a position that became increasingly difficult to sustain against the backdrop of escalating physical and verbal attacks on Jews.

But as we have seen, many Jews did not subscribe to these views. Even in the early years, organised Jewish opposition stretched across a wide canvas. In recognising a definite relationship between fascism and antisemitism, some Jews were drawn to the CPGB and its class-based analysis. Others, meanwhile, sought alliances between Jew and gentile in non-sectarian, democratic antifascist organisations. Finally, there were those who saw a need for the Jewish community to organise a body, independent of the Board of Deputies, that would counter antisemitism whilst also ensuring that Jewish youth was not drawn to Communistled antifascism. The communal divisions that emerged in 1936 were clearly foreshadowed in this earlier period.

Before 1937 many leading figures within the Board of Deputies' had clearly failed to understand or sympathise with communal demands for action, particularly those of working-class Jews that were directly threatened by the growth of fascism. This is in many ways unsurprising. These individuals were drawn largely from the social elites, and as such tended towards a conservative, gradualist approach, and were not in close contact with those at the lower end of the social scale. However, while traditional historical accounts have judged their attitude and policies largely on the basis of the period up to late 1936, closer examination reveals the evolution of their approach over the following years. It was quickly accepted that antisemitism had become an integral element of British fascism and that measures had to be taken against the movement itself. More importantly, it was now understood that, rather than endeavour to simply homogenise Anglo-Jewry, defence policy should reflect the diverse needs of the entire community. Equally, although some workingclass Jews remained suspicious of the Board and its motives, many, including those within the JPC, were increasingly prepared to accept its leadership in defence matters. ${ }^{104}$ Fascist antisemitism, had, therefore, helped bridge some of the divides between the two sides of Britain's Jewish community, as they sought to confront this common threat. 


\section{HOLOCAUST STUDIES: A JOURNAL OF CULTURE AND HISTORY}

\section{NOTES}

1. National Archives (NA) Metropolitan Police (MEPO) 2/3069.

2. Ibid.; Jewish Chronicle (JC), 12 May 1933; Times, 15 July 1933.

3. Thomas Linehan, East London for Mosley: The British Union of Fascists in East London and South-West Essex, 1933-40 (London: Frank Cass, 1996), p.59; Morning Advertiser, 30 March 1933, Golders Green Gazette, 31 March 1933; Blackshirt, 16 September 1933, p.3.

4. YCL, 10 Points Against Fascism (London: YCL, 1934), p.11.

5. Joe Jacobs, Out of the Ghetto (London: Phoenix Press, 1991), p.105.

6. JC, 5 May 1933 , p. 20.

7. NA Home Office (HO) 144/20140/135-8.

8. Jacobs, Out of the Ghetto, p.144.

9. NA MEPO 2/3074.

10. The Circle, December 1934, p.6, cited in Elaine Smith, 'Jewish Responses to Political Antisemitism and Fascism in the East End of London, 1920-1939', in Tony Kushner and Kenneth Lunn (eds.), Traditions of Intolerance: Historical Perspectives on Fascism and Race Discourse in Britain (Manchester: Manchester University Press, 1989), pp.62-3.

11. 'Sir Oswald Mosley and the Jews', Jewish Labour Council, date unknown. David Cesarani, 'The Transformation of Communal Authority in Anglo-Jewry, 1914-1940', in David Cesarani (ed.), The Making of Modern Anglo-Jewry (Oxford: Blackwell, 1990), pp.115-40, at p.129.

12. JC, 2 November 1934, p.6.

13. See Green Band, No.32, 12 May 1934, p.1.

14. JC, 6 July 1934, p.21. Note comments by Nathan Birch at NWF meeting in Trafalgar Square: 'We firmly believe that Fascism, as enunciated by these people, cannot develop in this country without making of the Jew a chopping-block as it has done in other parts of Europe. ... Some of the utterances of speakers of the Fascist organisations prove conclusively that during the whole of the last twelve months in the industrial areas of Great Britain they have made a dead-set against the Jews.'

15. NA MEPO 2/3043/289-94. The British Union of Democrats later merged with other antifascist organisations (British Democratic Association and the Legion of Blue and White Shirts) to become the Federation of Democrats. The Federation of Democrats protested against Mosley's procession through Bermondsey in October 1937. One of its leaders was Tim Walsh, formerly of the New World Fellowship.

16. JC, 22 February 1935, p.17 and 1 March 1935, p. 12 .

17. See Minutes of the Law, Parliamentary and General Purposes Committee (LPGPC), 15 October and 10 December 1934, London Metropolitan Archives (LMA), ACC 3121/C/13/1/12; Geoffrey Alderman, 'Dr Robert Forgan's resignation from the British Union of Fascists', Labour History Review, Vol.57, No.1 (Spring 1992), pp.37-41.

18. Cesarani, 'Transformation of Communal Authority', p.130.

19. David Rosenberg, Facing up to Antisemitism: How Jews Countered the Threats of the 1930s (London: JCARP Publications, 1985), p.13; David Cesarani, The Jewish Chronicle and Anglo-Jewry, 1841-1991 (Cambridge: Cambridge University Press, 1994), p.146.

20. On antifascist opposition to the New Party, see Nigel Copsey, 'Opposition to the New Party: An Incipient AntiFascism or a Defence Against "Mosleyitis"?', Contemporary British History, Vol.23, No.4 (2009), pp.461-75.

21. JC, 26 August 1932, p.8.

22. IC, 7 October 1932, p.8.

23. JC, 4 November 1932 , p.8.

24. JC, 13 January 1933, p.9; Blackshirt, 1 April 1932, p.1.

25. JC, 12 May $1933, \mathrm{p} .8$.

26. JC, 28 July 1933 .

27. JC, 12 May $1933, \mathrm{p} .8$.

28. JC, 4 August 1933, p.6.

29. Letter from Neville Laski to the Honorary Officers of the Board, 11 December 1934, LMA ACC 3121/E3/244. 
30. $J C, 8$ September $1933, \mathrm{p} .8$.

31. JC, 24 November 1933, p.8; Blackshirt, 4 November 1933.

32. $J C, 26$ January 1934, p. 14 .

33. $J C, 2$ February 1934, p.16.

34. JC 20 April 1934, p.7.

35. JC, 15 June 1934 , p.10; see Blackshirt, 2 July 1934, p.2.

36. $J C, 27$ July 1934, p.8.

37. JC, 27 July 1934, p.8.

38. JC, 16 November 1934, p. 26

39. JC, 2 November 1934, p.8.

40. Rosenberg, Facing up to Antisemitism, p.42.

41. Elaine Smith, 'But What Did They Do? Contemporary Jewish Responses to Cable Street', in Tony Kushner and Nadia Valman (eds.), Remembering Cable Street: Fascism and Anti-Fascism in British Society (London: Vallentine Mitchell, 2000), pp.48-9, 53.

42. Gisela Lebzelter, Political Anti-Semitism in England 1918-1939 (London: Macmillan, 1978), pp.139, $144-5$.

43. Neil Barrett, 'The Threat of the British Union of Fascists in Manchester', in Kushner and Valman, Remembering Cable Street, pp.56-73.

44. Cesarani, 'Transformation of Communal Authority', pp.130-31.

45. Geoffrey Alderman, Modern British Jewry (Oxford: Oxford University Press, 1998), pp.285-6, 293.

46. Jewish Chronicle, 15 May 1936, p.9; Letter from Neville to Nathan Laski, 22 July 1936, LMA ACC $3121 / \mathrm{E} 3 / 245 / 2$

47. Minutes of the LPGPC, 15 November 1938. It was also felt that changing the committee's name would encourage further donations towards its funding.

48. Letter from Neville Laski to Nathan Laski, 22 July 1936, and letter from A.G. Brotman to the secretary of the South African Board of Deputies, 24 August 1936, LMA ACC 3121/E3/245/2.

49. A fifth, involving more directly antifascist activity, was soon added. See Daniel Tilles, "Some Lesser Known Aspects": The Anti-Fascist Campaign of the Board of Deputies of British Jews', in Geoffrey Alderman (ed.), New Directions in Anglo-Jewish History (Boston: Academic Studies Press, 2010).

50. Examples include: 'What the Jews of the British Empire did in the Great War', 'International Finance: More Fascist Lies Exposed' and 'Be on your guard! How fascists work', Zaidman Collection (ZC), Sheffield University Archives.

51. See letter to Worcester Daily Times from 'Aletheia', 21 July 1936, and letter from A.G. Brotman to Rabbi Ginsberg, 23 June 1936, LMA ACC 3121/E3/245/2.

52. See Manchester Guardian, 7 September 1936. For the Board's guidelines for speakers see Frank Renton, Jewish Defence Campaign - Speakers Handbook (London: Woburn Press, 1937), and the series of 'Speakers' Notes' booklets published by Woburn Press in the late 1930s, ZC, 118/4/48.

53. 'The Problem and Meaning of Jewish Defence', Jewish Defence Committee, undated, p.5, LMA ACC3121/G1/3/34.

54. Sidney Salomon, Anti-Semitism and Fascism in Post-War Britain. The Work of the Jewish Defence Committee (London: Woburn Press, 1950), pp.12-13.

55. Letter from Charles Emanuel to the Sunday Times, 21 July 1936, LMA ACC 3121/E3/245/2.

56. Letter from Brotman to secretary of the South African Board of Deputies, 24 August 1936, LMA ACC/3121/E3/245/2. Salomon, Anti-Semitism and Fascism, p.3. A leading fascist later lamented the 'total silence' in the press when BUF events passed without incident, complaining that it was only when their opponents initiated violence that newspapers became interested, Mosley's Blackshirts (London: Sanctuary Press, 1986), p.63.

57. Letters from Sir Russell Scott and Sir Philip Game to Laski, 14 December 1936, 30 July 1937 and 15 June 1938, LMA ACC/3121/E3/245/1, 242/2 and 247; 'Public Meetings' report, 10 February 1936, NA MEPO 2/3085.

58. Memorandum on meeting at Stepney Town Hall, 11 October 1936, ACC/3121/E3/245/2.

59. Alderman, Modern British Jewry, p.286.

60. Cesarani, The Jewish Chronicle, pp.156-9. 


\section{HOLOCAUST STUDIES: A JOURNAL OF CULTURE AND HISTORY}

61. Memorandum on meeting at Stepney Town Hall, 11 October 1936, ACC/3121/E3/245/2.

62. Barrett, 'The BUF in Manchester', p.62.

63. See minutes of LPGPC. For magistrate's comment, see minutes of 16 November 1937.

64. Ibid., especially minutes of 10 July 1934 and 14 June 1938 .

65. Alderman, Modern British Jewry, p.295; Salomon, Anti-Semitism and Fascism. In 1940, with its attitude increasingly divergent from that of the JDC, the TAC became an independent body.

66. Neville Laski, Jewish Rights and Jewish Wrongs (London: Sorcino Press, 1939), pp.123-5, 139-41.

67. For an outline of the Board's attitude, see ibid., pp.113-41; Alderman, Modern British Jewry, p.290.

68. Ibid., p.293; Nigel Copsey, Anti-Fascism in Britain (Basingstoke: Macmillan, 2000), pp.50-51.

69. "British Fascism" and the Jews', ACC 3121/E3/245/2; Sidney Salomon, The Deputies - A Short Historical Survey (London: V.W.H. Press, 1937). Magnus had actually shown an early interest in fascism, attending meetings of Mosley's 'January Club' in 1934 before the BUF had officially adopted antisemitism (although after it had begun to demonstrate signs of anti-Jewish prejudice); Geoffrey Alderman, The Jewish Community in British Politics (Oxford: Oxford University Press, 1983), p.195.

70. Letter from unknown BoD official to T. Fligelstone, 25 February 1937, LMA ACC 3121/E3/245/1. The Board was also bold enough to send a representative to a JPC conference in late 1936 to request that it fight against antisemitism but not fascism itself - a proposal that was 'unfavourably received', Daily Worker, 16 November 1936

71. "British Fascism" and the Jews'.

72. Letter from Neville Laski to Sir Albert Clavering, 29 June 1936, LMA ACC 3121/E3/244.

73. The JPC was formed at a conference of 181 delegates representing no fewer than 87 Jewish organisations, see 'Jewish People's Council Against Fascism and Anti-Semitism and the Board of Deputies' (London: JPC, 1936?).

74. Lebzelter, Political Anti-Semitism, p.142; NA MEPO $2 / 3112$.

75. Copsey (Anti-Fascism in Britain, p.53) notes that the Board's suspicions were, superficially at least, 'well grounded'. Many leading figures in the JPC were members of the CPGB, including its secretary, Jack Pearce, and the two organisations enjoyed a close, if unofficial, relationship. The National Council for Civil Liberties, with whom the JPC worked closely, was similarly connected to the Communists.

76. 'Memorandum on the Situation in the East End', ACC 3121/E3/245/1.

77. Letter from Neville Laski to Sir Philip Game, 1 December 1937, ibid.

78. Smith, 'Jewish Responses', p.66; Copsey, Anti-Fascism in Britain, pp.74-6; Tony Kushner, The Persistence of Prejudice (Manchester University Press, 1989), pp.166-7; Rosenberg, Facing up to Antisemitism, p.59.

79. Anti-Semitism in the East End' (London: Woburn Press, 1936); 'Do you know these facts about Mosley and his Fascists?' (London: Woburn Press, 1937).

80. Neville Laski, 'Memorandum of Certain Activities in Reaction - October 1937'; letter from unknown BoD official (probably Laski) to Edward Iwi, 11 February 1938, ACC 3121/E3/245/1.

81. See Tilles, "Some Lesser Known Aspects"; and Thurlow, Fascism in Britain: From Oswald Mosley's Blackshirts to the National Front (London: I.B. Tauris, 1998), pp.52-3, 211-12.

82. LMA ACC 3121/E3/245/2; letter from unknown BoD official to Edward Iwi, 11 February 1938, LMA ACC 3121/E3/245/1.

83. Letters from Laski to George Webber and Sir Robert Waley Cohen, 11 May 1937, LMA ACC 3121/E3/245/1; letter from unknown Board official (almost certainly Laski) to Sir Philip Game, 22 July 1938, LMA ACC $3121 / \mathrm{E} 3 / 247$.

84. The report of this meeting, which took place on 8 July 1936, can be found in LMA ACC 3121/E3/245/2

85. Unsigned letter from Laski to Sir Russell Scott, 8 March 1937, LMA ACC 3121/E3/245/1.

86. Evening Standard, 4 November 1936.

87. Letters from Sir Philip Game to Neville Laski, 30 July 1937, and Laski to Game, 15 August 1937, ACC 3121/E3/245/2; Minutes of the LPGPC, 16 November 1937, 14 December 1937, and 15 February 1938.

88. See, for example, letters from Game to Laski, from Laski to Game and from Laski to Cyril Picciotto, 15 June 1938, ACC 3121/E3/247. On the police's unwillingness to have any direct contact with the JPC, see letters from unknown sender at New Scotland Yard to Laski, 16 August 1937, ACC 3121/E3/245/2 and from Sir Samuel Hoare's private secretary to Ronald Kidd, 21 June 1937, Hull University Archive, DCL/8/5. 
89. H. Solomons, 'Conditions in the East End', 21 June 1937, ACC 3121/E3/247; letter from Laski to Sir Russell Scott, 8 March 1937.

90. Salomon, Anti-Semitism and Fascism, p.11; JC, 20 August 1937.

91. JC, 16 October 1936; Daily Worker, 16 November 1936; untitled report, 24 June 1937, Spector Collection, Wiener Library, 610/1.

92. Smith, 'Jewish Responses', p.66; Copsey, Anti-Fascism in Britain, p.73.

93. See letters from unknown sender to Brotman, 1 November 1937 and from Order Achei Ameth to Brotman, 20 April 1937, LMA ACC 3121/E3/245/1.

94. Letter to Laski from 'Secretary', 22 July 1938; letter from senior Board official (likely to be Laski) to Councillor M.E. Waldman, 14 November 1938, LMA ACC 3121/E3/247.

95. These aims were outlined in Vigilance, the organ of the JPC, and are summarised in a Home Office report, NA MEPO 2/3112.

96. This stance was advocated by J. Jacobs, the JPC's chairman, at a conference in April 1937, JC, 30 April 1937.

97. 'The Jews - Are They Hated?' (London: Woburn Press, 1939), p.4.

98. David Cesarani, Reporting Anti-Semitism: The Jewish Chronicle 1879-1979 (University of Southampton, 1993), pp.25-7, and 'Transformation of Communal Authority', pp.128-9; Smith, 'Jewish Responses', p.67; Rosenberg, Facing up to Antisemitism, p.6.

99. Cesarani ('Transformation of Communal Authority', pp.139-40) argues that the appointment of Brodetsky, who was a leading Zionist, owed more to the growing influence of middle-class Zionists at the expense of the declining traditional elites. However, communal change was a multilateral process pressure from working-class Jews, in particular over defence, and a growing willingness to compromise on the part of the elites also played important roles. Such change was also gradual, as evidenced by the fact that of the CoC's ten members in mid-1937, half were still in place on the JDC eight years later. See minutes of the LPGPC, 1 June 1937 and 'The Problem and Meaning of Jewish Defence'.

100. Linehan, East London for Mosley, pp.199-200

101. Laski, Jewish Rights, p.133.

102. Copsey, Anti-Fascism in Britain, pp.40-41

103. JC, 30 March 1934, p.16.

104. There were, of course, elements within the Jewish community that continued to pursue a more physical approach to antifascism in the late 1930 s, and such activity resumed after the war, most famously in the form of the 43 Group, which was established to combat the re-emergence of British fascism. It is interesting to note that the Board's efforts to bring the 43 Group to heel strongly mirrored their interaction with the JPC a decade earlier, and the 43 Group eventually agreed to absorb itself into the official communal defence machinery in 1950. See Copsey, Anti-Fascism in Britain, pp.93-4, 98-101. 